\title{
Preparation and characterization of a packed bead immobilized trypsin reactor integrated into a PDMS microfluidic chip for rapid protein digestion
}

\author{
Adam Kecskemeti, Attila Gaspar* \\ Department of Inorganic and Analytical Chemistry, University of Debrecen, Egyetem ter 1, Debrecen 4032, Hungary
}

\section{ART ICLE INFO}

\section{Keywords:}

Trypsin immobilization

Protein digestion

Peptide mapping

Microchip reactor

\begin{abstract}
A B S T R A C T
This paper demonstrates the design, efficiency and applicability of a simple, inexpensive and high sample throughput microchip immobilized enzymatic reactor (IMER) for rapid protein digestion. The IMER contains conventional silica particles with covalently immobilized trypsin packed inside of a poly(dimethylsiloxane) (PDMS) microchip channel $(10 \mathrm{~mm} \times 1 \mathrm{~mm} \times 35 \mu \mathrm{m})$. The microchip consists of 9 different channels, enabling 9 simultaneous protein digestions. Trypsin was covalently immobilized using carbodiimide activation, the ideal trypsin/silica particle ratio (i.e. measured mass ratio before the immobilization reaction) was determined. The amount of immobilized trypsin was 10-15 $\mu \mathrm{g}$ trypsin for $1 \mathrm{mg}$ silica particle. Migration times of CZE peptide maps showed good repeatability and reproducibility (RSD $\%=0.02-0.31 \%$ ). The IMER maintained its activity for 2 months, in this period it was used effectively for rapid proteolysis. Four proteins (myoglobin, lysozyme, hemoglobin and albumin) in a wide size range (15-70 kDa) were digested to demonstrate the applicability of the reactor. Their CZE peptide maps were compared to peptide maps obtained from standard in-solution digestion of the four proteins. The number of peptide peaks correlated well with the theoretically expected peptide number in both cases, the peak patterns of the electropherograms were similar, however, digestion with the microchip IMER requires only $<10 \mathrm{~s}$, while in-solution digestion takes $16 \mathrm{~h}$. LC-MS/MS peptide mapping was also carried out, the four proteins were identified with satisfying sequence coverages (29-50\%), trypsin autolysis peptides were not detected. The protein content of human serum was digested with the IMER and with in-solution digestion.
\end{abstract}

\section{Introduction}

Proteomics is a relevant field of study in bioanalytics, aiming at the characterization of the entire set of proteins expressed by a genome [1]. Proteome research underwent a substantial evolution with the appearance of peptide mapping, a method used for the identification of proteins or the analysis of their primary structure or posttranslational modifications. Later, the emergence of modern LC-MS/MS systems contributed to the pioneering development of shotgun proteomics, which enabled the analysis of several hundreds of proteins in a single experiment [2].

Peptide mapping includes the chemical or enzymatic digestion of a protein sample, the analysis of the digest and the comparison of the obtained peptide map with a peptide database [3]. Firstly, proteins are denatured and their disulphide bridges are reduced and alkylated to fa- cilitate enzymatic digestion. Trypsin is a proteolytic enzyme widely used for protein digestion; it cleaves the amino acid sequence at the C-terminal peptide bonds of lysine and arginine. After digestion, the reaction mixture is desalted and the peptides are separated and detected. For this analysis, (two dimensional) high performance liquid chromatography ((2D) HPLC) [4,5], capillary electrophoresis (CE) [5-8], matrix-assisted laser desorption/ionization mass spectrometry (MALDI-MS) [9], CE-MS [10] or LC-MS/MS $[2,11,12]$ techniques are preferably used. The obtained peptide map describes the sample protein as a fingerprint, enabling protein identification or the analysis of posttranslational modifications [13].

The most time consuming step of the analysis is the enzymatic digestion with trypsin $(2-30 \mathrm{~h})$, as it can only be applied in low concentrations (protein:enzyme $=20-100: 1$ ) due to its undesirable self-digestion in free form. Self-digestion can be prevented with the immobi-

Abbreviations: IMER, immobilized enzymatic reactor; PDMS, poly(dimethylsiloxane); CZE, capillary zone electrophoresis.

Corresponding author.

Email address: gaspar@science.unideb.hu (A. Gaspar) 
lization of trypsin onto a solid support, thus it is possible to utilize the enzyme in higher surface concentration.

There are numerous advantages of using immobilized enzymes: reusability, prolonged lifetime, easy separation from products and substrate specificity. They also have diverse applications such as the design of biosensors [14], enzymatic microreactors [15] or improving enzyme stability [16]. In general, enzymes can be immobilized on solid supports via adsorption [17-23], covalent linkage [6,9,11,22,24-44] or bioaffinity linkage [45-47].

The use of immobilized trypsin for protein digestion is especially beneficial in a system with high surface-to-volume (S/V) ratio, as high $\mathrm{S} / \mathrm{V}$ ratio favors the heterogenic reaction between the free substrate and the immobilized trypsin, hence reaction times are greatly reduced (10 s-15 min) [48]. One possible design for the preparation of immobilized enzymatic reactors (IMER) is to use the capillary/channel walls of fused silica capillaries or microchips as solid supports for immobilization $[22,26,45-47,49]$. In order to further increase the $S / V$ ratio of the reactor, a more often used approach is to apply solid supports with even higher specific surface area integrated into microfluidic chips or capillaries, e.g. membranes [17-19, 21], mesoporous silica [20,23], monoliths $[6,11,24,25,33-37,44,50]$, magnetic microspheres/ beads [27,38-43,51], silica particles (packing or column) [28,29] or commercially available beads (usually cross-linked agarose) [5,31,52-54]. These microchip IMERs are capable of rapid protein digestion and can operate with small sample and reagent volumes. As microfluidic chips can be coupled to separation techniques (CE or MS) $[9,22,48,50,52,55-59]$, they can be used advantageously for on-line proteolysis. In these systems, protein samples are usually digested in the microchip IMER and the resulting peptides are separated and detected (with CE and/or MS).

Microfluidic chips are routinely fabricated of poly(dimethylsiloxane) (PDMS) using soft lithography [60]. As the simplest approach, the complex microscopic channel network can be directly applied as a support for immobilization due to its high S/V ratio. For covalent protein immobilization on PDMS surface, complex chemical reactions are necessary for surface modification as PDMS lacks reactive groups [22]. In an earlier work our group showed that conventional chromatographic particles can be retained in a PDMS microchip without the use of frits but only with simple bottlenecks [61-63]. The obtained chromatographic packings were applicable for chromatographic separation/preconcentrations of components.

In this work we demonstrate the fabrication and usability of a packed bead immobilized enzymatic reactor integrated into a PDMS microfluidic chip. For high S/V ratio, we used trypsin coated silica particles to create packings inside the microchip channels. To the best of our knowledge, this is the first work describing an enzymatic reactor integrated into a PDMS microfluidic chip containing covalently immobilized trypsin on conventional (chromatographic) silica particles. The efficiency of the microchip IMER was evaluated with capillary zone electrophoresis (CZE) and LC-MS/MS measurements after digestion.

\section{Experimental}

\subsection{Materials}

Analytical grade reagents were used. To establish covalent linkage between trypsin (Type IX-S, lyophilized powder, Sigma, St. Louis, MO, USA) and amino-functionalized silica particles (HPLC bulk packing, Microsorb 100-5, amino, Varian, Palo Alto, CA, USA) N-(3-dimethylaminopropyl)- $\mathrm{N}^{\prime}$-ethylcarbodiimide hydrochloride (EDC), N-hydroxysuccinimide (NHS) and benzamidine hydrochloride were used (all Sigma products).
For protein determination by Lowry's method [64], the three components of the Lowry solution were prepared as stock solutions and the final Lowry solution was prepared freshly before each experiment, according to the manufacturer's protocol (Sigma). For the three stock solutions, $\mathrm{NaOH}, \mathrm{Na}_{2} \mathrm{CO}_{3}, \mathrm{CuSO}_{4}$ and potassium sodium tartrate were used (all Sigma products). Also, Folin and Ciocalteu's phenol reagent $(2 \mathrm{~N})$ was used for the determination (Sigma).

Bovine serum albumin (BSA), lysozyme from egg white, equine skeletal muscle myoglobin and bovine blood hemoglobin (Sigma) were digested. As realistic sample, human blood serum obtained from a healthy volunteer was digested. For sample preparation, $1 \mathrm{mM}$ trifluoroacetic acid (TFA), $8 \mathrm{M}$ urea, $100 \mathrm{mM}$ dithiothreitol (DTT), $200 \mathrm{mM}$ iodoacetamide (IAM), $25 \mathrm{mM} \mathrm{NH}{ }_{4} \mathrm{HCO}_{3}$ and $1 \%$ formic acid (FA) stock solutions (all Sigma products) were prepared in double-deionized water (Elix-3, Millipore, Darmstadt, Germany).

For capillary zone electrophoretic measurements, $\mathrm{NaH}_{2} \mathrm{PO}_{4}$, $\mathrm{Na}_{2} \mathrm{HPO}_{4}$, sodium dodecyl sulfate (SDS, $50 \mathrm{mM}$ ) and $\mathrm{NaOH}(1 \mathrm{M})$ (VWR International, PA, USA) were dissolved in double-deionized water.

\subsection{Instruments}

An inverted microscope (Axio ObserverA1, Zeiss) equipped with a high speed CCD camera was used to record images of the packing process. Images were processed by AxioVision 4.6.3 (Zeiss) software.

$\mathrm{UV} / \mathrm{V}$ is spectrophotometry for the determination of immobilized trypsin was carried out on a double-beam spectrophotometer (V-550, Jasco).

Capillary zone electrophoretic (CZE) peptide mapping was performed using a 7100 model CE instrument (Agilent, Waldbronn, Germany). The electropherograms were recorded and processed by ChemStation software version B.04.02 (Agilent).

Mass spectrometry analyses were done on a 4000 QTRAP (ABSciex)- EasynLC II (Bruker) nanoHPLC-MS/MS System controlled by Analyst 1.4.2 (ABSciex) software. Information Dependent Acquisition was carried out composed of a positive mode survey scan (+EMS) in 440-1400 amu mass range followed by an enhanced resolution scan ( $+\mathrm{ER}$ ) in order to determine the charge state of the two most intensive ions. Using these information, the proper collision energies were calculated by the software, the selected parent ions were fragmented by collision induced dissociation (CID) and the product ion spectra were recorded (+EPI).

\subsection{Preparation of the microchip IMER}

The IMER was integrated into a PDMS microfluidic chip consisting of 9 parallel channels with $1 \mathrm{~mm}$ width, $10 \mathrm{~mm}$ length and $35 \mu \mathrm{m}$ height (internal volume: $350 \mathrm{~nL}$ ). The chip was fabricated by means of soft photolithography [60]. Briefly, the lithographic mask was designed with AutoCAD software and was printed in high resolution (3000 dpi) onto a transparent foil. A 3" silicon wafer was spin-coated with negative type photoresist (SU-8 2025, Microchem, Newton, MA, USA) at $3000 \mathrm{rpm}$ for $15 \mathrm{~s}$ to achieve a thickness of $\sim 35 \mu \mathrm{m}$. After spin-coating, the wafer was baked at $95{ }^{\circ} \mathrm{C}$ for $15 \mathrm{~min}$. The pattern on the mask was transferred to the wafer through UV exposure ( $365 \mathrm{~nm}$ ) for $10 \mathrm{~min}$. The exposed wafer was baked at $95{ }^{\circ} \mathrm{C}$ for $5 \mathrm{~min}$ and the unexposed areas were removed by rinsing with SU-8 developer (Microchem).

The PDMS chip was fabricated by cast molding a 10:1 (w:w) mixture of silicone elastomer base and curing agent (Sylgard 184, Dow Corning, Midland, MI, USA). The mixture was degassed and baked at $65{ }^{\circ} \mathrm{C}$ for $60 \mathrm{~min}$. Holes ( $300 \mu \mathrm{m}$ diameter) were pierced through the PDMS chip at the ends of the channels for liquid connections. The 
PDMS chip was irreversibly sealed onto a $1.2 \mathrm{~mm}$ thick glass slide after oxygen plasma treatment (PDC-32G, Harrick, Ithaca, NY, USA).

A peristaltic pump (IPC, Ismatec, Cole-Palmer, IL, USA) was used for the transportation of reagents and samples through the microfluidic channel. The tubing of the pump (ID: $0.25 \mathrm{~mm}$, Tygon, Cole-Palmer, IL, USA) was connected to the inlet port of the chip.

Trypsin was covalently immobilized using EDC/NHS method (Fig. 1a): trypsin $(3 \mathrm{mg} / \mathrm{mL}), \mathrm{EDC}(7 \mathrm{mg} / \mathrm{mL})$ and NHS $(1.3 \mathrm{mg} / \mathrm{mL})$ were dissolved in $50 \mathrm{mM}$ phosphate buffer $(\mathrm{pH}=6.8)$ [26], which contained suspended amino-functionalized silica particles $(12 \mathrm{mg} / \mathrm{mL})$ and the mixture was stirred for $5 \mathrm{~h}$. After immobilization, the suspension was transferred into a $2 \mathrm{~mL}$ Eppendorf tube, the particles were centrifuged and the supernatant was decanted. $1.5 \mathrm{~mL}$ mixture of acetonitrile:water (70:30) was added to the particles, vortexed for $1 \mathrm{~min}$, centrifuged and decanted again. This washing step was repeated 6 times to completely remove any free trypsin, using $1.5 \mathrm{~mL}$ acetonitrile:water (70:30) and $1.5 \mathrm{~mL}$ water, alternatingly. After the last washing step, $200 \mu \mathrm{L}$ solution of $1 \mathrm{mM} \mathrm{HCl}, 20 \mathrm{mM} \mathrm{CaCl}_{2}$ and $0.4 \mathrm{mg} / \mathrm{mL}$ benzamidine was added to the particles (storage solution) and the suspension was stored at $-18{ }^{\circ} \mathrm{C}$ until use. To create the microchip IMER, the silica particles with the immobilized trypsin were packed inside the channels of a PDMS chip.

In several papers regarding immobilized trypsin [65-70], benzamidine is used as competitive inhibitor, which binds into the active site of the enzyme, protecting it during immobilization or storage. The effect of using benzamidine in the immobilization reaction was studied, in this case the mixture contained $0.4 \mathrm{mg} / \mathrm{mL}$ benzamidine, as well. It was found that in our case, the use of benzamidine during the immobilization reaction did not offer any elevated activity of the immobilized trypsin. As a result, benzamidine was used only for protecting trypsin upon storage but not for protection during immobilization. More details on this experiment are available in the Supplementary material (Fig. S.1).

The proper preparation of packings was pivotal for the analysis, as sufficiently compressed packings were needed for reproducible and effective proteolysis. The designed PDMS chip contained $1 \mathrm{~mm}$ thick channels which ended in 5 bottlenecks of $20 \mu \mathrm{m}$ width each. The sus- pension of the particles containing immobilized trypsin was injected, $\sim 2.5 \mu \mathrm{L}$ suspension was necessary to form a $1 \mathrm{~cm}$ long packing (Fig. 1b-e). $25 \mathrm{mM} \mathrm{NH}_{4} \mathrm{HCO}_{3}(\mathrm{pH}=7.8)$ was flushed through the channel with $1 \mu \mathrm{L} / \mathrm{min}$ flow rate for $10 \mathrm{~min}$ to compress the particles and to precondition the trypsin at an optimal $\mathrm{pH}$.

\subsection{Enzymatic digestion}

Protein samples were pretreated in order to facilitate enzymatic digestion: $\sim 2,5 \mathrm{mg}$ protein sample was dissolved in $100 \mu \mathrm{L} 1 \mathrm{mM}$ TFA (in the case of human serum: $20 \mu \mathrm{L}$ serum was diluted with $80 \mu \mathrm{L}$ TFA) and immediately $300 \mu \mathrm{L} 8 \mathrm{M}$ urea solution was added. After $30 \mathrm{~min}$ at room temperature, the tertiary structure of the protein was unfolded, then, $40 \mu \mathrm{L} 100 \mathrm{mM}$ DTT was added to reduce disulphide bonds $(1 \mathrm{~h}$ at $37{ }^{\circ} \mathrm{C}$ ). Subsequently, $40 \mu \mathrm{L} 200 \mathrm{mM}$ IAM as an alkylating agent was added to avoid the recombination of the disulphide bonds (45 min at room temperature in dark). $2 \mathrm{~mL} 25 \mathrm{mM} \mathrm{NH}_{4} \mathrm{HCO}_{3}$ was further added to the mixture to give a final urea concentration $1 \mathrm{M}$ (protein concentration: $\sim 1 \mathrm{mg} / \mathrm{mL}$ ). The prepared solutions were stored at $-18{ }^{\circ} \mathrm{C}$ until digestion either in-solution or in the microchip IMER.

For in-solution digestion, $1 \mathrm{mg} / \mathrm{mL}$ trypsin was added to the sample (protein:trypsin $=50: 1)$. After overnight $(16 \mathrm{~h})$ incubation at $37^{\circ} \mathrm{C}$, the reaction was terminated with the addition of $250 \mu \mathrm{L} 1 \%$ FA to the mixture.

For the digestion with the microchip IMER, the sample was flushed through the packing with $1 \mu \mathrm{L} / \mathrm{min}$ (contact time $<10 \mathrm{~s}$ ). $10 \mu \mathrm{L}$ sample was collected at the outlet end of the microchip channel, this sample volume was necessary for CZE separation after desalting. Digestion occurred at room temperature. With the microchip IMER, 9 different protein samples can be digested at the same time (Fig. 1f). After each digestion, the packings were postconditioned by flushing it with acetonitrile:water (20:80) containing $25 \mathrm{mM} \mathrm{NH}_{4} \mathrm{HCO}_{3}$ for $10 \mathrm{~min}$ [24].

Desalting was performed on C18 Supel-Tips (SupelCo, Sigma), according to the manufacturer's manual. $0.1 \%$ FA was used as wetting and desalting solution and acetonitrile:water (70:30) containing $0.1 \%$ FA to elute the adsorbed peptides to $10 \mu \mathrm{L}$ final volume.
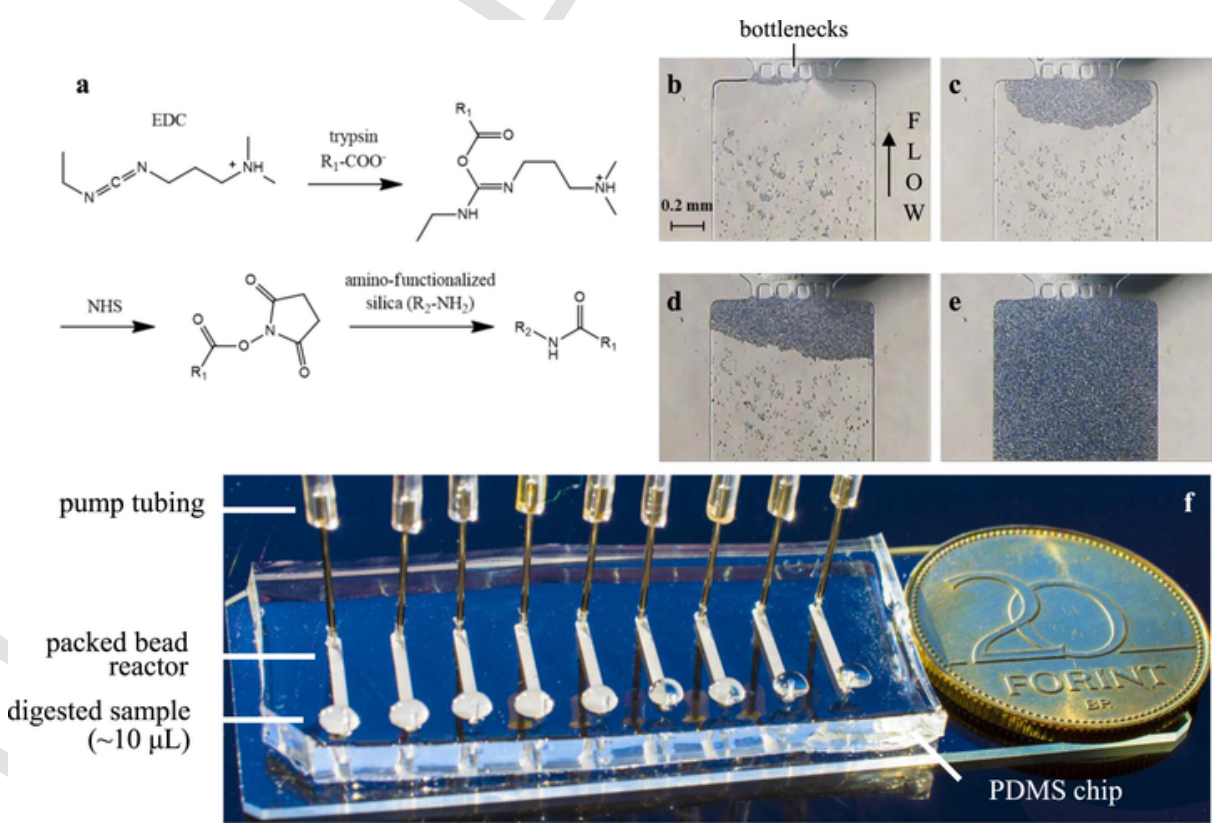

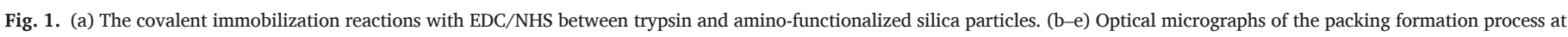
the bottlenecks. The suspension of the silica particles in storage solution was pumped toward the bottlenecks. (f) Photograph of the microchip IMER with 9 simultaneous digestions. 


\subsection{CZE separation}

In all measurements hydrodynamic sample introduction was used for injecting samples. The sample solutions were introduced at the anodic end of the capillary. Capillary zone electrophoresis separations were carried out using fused-silica capillaries of $80 \mathrm{~cm} \times 50 \mu \mathrm{m}$ id (Agilent) with extended light path. The applied voltage was $30 \mathrm{kV}$. The detection was carried out by on-column DAD measurement. The buffer electrolyte for the CZE separation contained $25 \mathrm{mM}$ phosphate, $\mathrm{pH}$ 7.0. The capillaries were preconditioned with the buffer electrolyte for $5 \mathrm{~min}$ and postconditioned with $50 \mathrm{mM}$ SDS for $5 \mathrm{~min}, 1 \mathrm{M} \mathrm{NaOH}$ for $10 \mathrm{~min}$ and the buffer electrolyte for $5 \mathrm{~min}$. Each sample contained $\sim 1 \mathrm{mg} / \mathrm{mL}$ protein (prior to digestion).

\subsection{LC-MS/MS measurements}

Desalted samples for LC-MS/MS analysis were diluted to a 10-fold final volume ( $1 \mu \mathrm{L}$ desalted sample with $9 \mu \mathrm{L} 1 \%$ FA). Prior to mass spectrometry analysis, the peptides were separated using a $90 \mathrm{~min}$ water:acetonitrile gradient and $300 \mathrm{~nL} / \mathrm{min}$ flow rate on an EasynLC (Bruker) nanoHPLC. First a desalting step was performed on a Zorbax 300 SB-C18 column $(5 \times 0.3 \mathrm{~mm}, 5 \mu \mathrm{m}$ pore size; Agilent) followed by separation on a Zorbax 300SB-C18 analytical column (150 $\mathrm{mm} \times 75 \mu \mathrm{m}, 3.5 \mu \mathrm{m}$ pore size; Agilent). Solvent A was $0.1 \% \mathrm{FA}$ in LC water, solvent B was acetonitrile containing $0.1 \%$ FA. The acquired LC-MS/MS spectra were used for protein identification with the help of ProteinPilot 4.0 (ABSciex) search engine searching the SwissProt database (release: 2015.07, 548,872 sequence entries) using the biological modification table included in the ProteinPilot 4.0 software. Minimum of two peptide sequences with $\geq 95 \%$ confidence were used for protein identification.

\section{Results and discussion}

\subsection{Determination of the immobilized trypsin}

An important aspect in the characterization of an IMER is the amount of immobilized enzyme as it determines the maximal activity. In the case of tryptic proteolysis, digestion rate in a reactor with high $\mathrm{S}$ / $\mathrm{V}$ ratio depends only on the protein:trypsin ratio (under permanent temperature and $\mathrm{pH}$ ). Obviously, digestion occurs more rapidly if trypsin is present in higher surface concentration.

Quantitative determination of the immobilized trypsin was carried out to estimate the ideal concentrations of trypsin and silica particles (that is the measured mass ratio before the immobilization reaction). Enzyme immobilization was achieved as described earlier, different trypsin/silica particle ratios were used. Determination of the immobilized trypsin can be performed according to Lowry's method after the basic cleavage $(0.1 \mathrm{M} \mathrm{NaOH})$ of the already immobilized trypsin from the solid support, if it is linked as an amine (e.g. glutaraldehyde linkage) [24]. In this study, trypsin was linked to the solid support through a peptide bond, which is more stable under basic conditions, however, determination of the immobilized trypsin can be carried out similarly, as $\mathrm{NaOH}$ attacks silica under the trypsin, thus mobilizes it.

After immobilization and washing, the full amount of particles was transferred into a $10 \mathrm{~mL}$ volumetric flask with $0.1 \mathrm{M} \mathrm{NaOH}$ and it was stirred for $2 \mathrm{~h}$ at room temperature. The amount of immobilized trypsin was determined from the supernatant according to Lowry's method. Also, control immobilized trypsin determination without the use of EDC and NHS was performed to prove that the formation of covalent linkage (the presence of EDC and NHS in the immobilization mixture) was responsible for the immobilization of trypsin.
It is noteworthy that the amount of immobilized trypsin depended on the initial concentrations of silica particles and trypsin. As Fig. 2 shows, the increase of trypsin/particle ratio up to $\sim 250 \mu \mathrm{g} / \mathrm{mg}$ increased the immobilized trypsin/particle (i.e. surface trypsin concentration) linearly, however, increasing it furtherly did not affect the surface trypsin concentration. This can presumably be attributed to the saturation of the silica particle surface by trypsin, with no binding place remaining. An ideal initial trypsin/particle ratio should guarantee that the full surface of the particle is saturated with trypsin and the amount of prepared particles is the largest possible, therefore, $250 \mu \mathrm{g} / \mathrm{mg}$ ratio was applied in our experiments for trypsin immobilization.

Control measurements were carried out without the use of EDC/NHS in the immobilization reaction. Under these initial circumstances, no covalent linkage occurs, therefore, the determined concentration (1-3 $\mu \mathrm{g}$ / $\mathrm{mg}$ ) can be attributed to trypsin spontaneously adsorbed onto the particles and not removed in the washing steps and/or the experimental error. The significant difference in the amount of immobilized trypsin upon using EDC and NHS as coupling agents proves that covalent linkage was formed between trypsin and amino-functionalized silica particles. Also, the determination leads to $\sim 10 \mu \mathrm{g} / \mathrm{mg}$ immobilized trypsin/ particle if it was corrected with the control measurement, which is comparable to or higher than other works determining immobilized trypsin in a similar system (e.g. 2 and $10 \mathrm{~cm}$ long reactor with $1.3 \mu \mathrm{g}$ trypsin/ $1 \mathrm{~cm}$ length for a silica monolith reactor [24], $1.5 \mathrm{~cm}$ long reactor with $0.9 \mu \mathrm{g} / 1 \mathrm{~cm}$ gel in a trypsin-encapsulated gel reactor [71] and a $1 \mathrm{~cm}$ long reactor with $97 \mathrm{ng}$ trypsin/1 cm length in a PSG/PEG monolith reactor [33]).

Rapid digestion requires high trypsin surface concentration. To calculate the trypsin/protein ratio in the microchip IMER, two suggestions should be made: (i) the mass of a single packing is $\sim 0.5 \mathrm{mg}$ (cf. the channel's inner volume is $350 \mathrm{~nL}$ ) and (ii) the dead volume of the
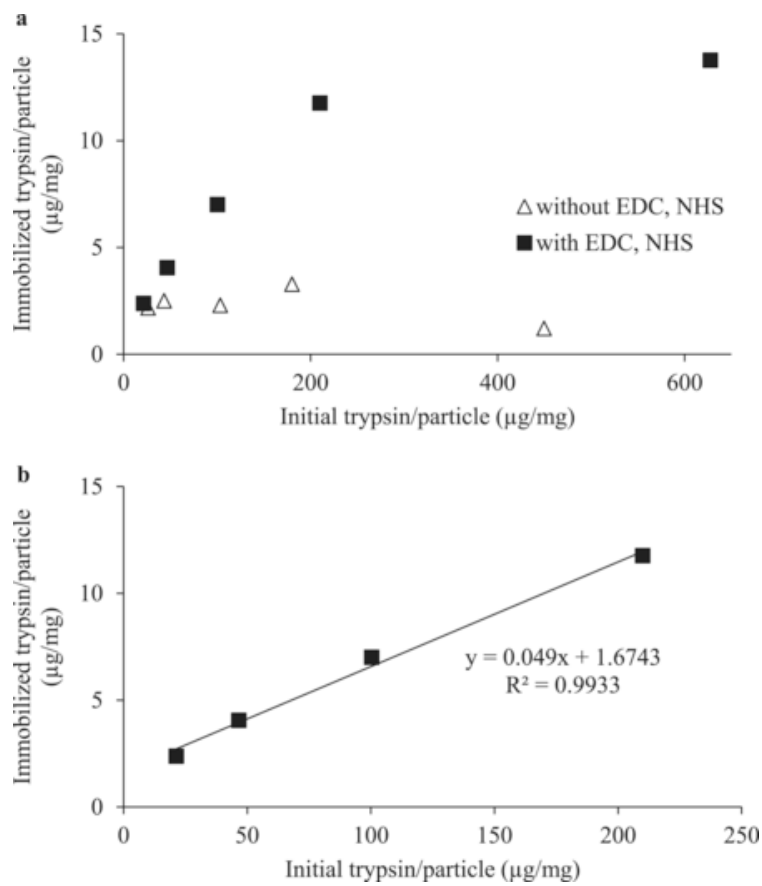

Fig. 2. (a) Dependence of trypsin surface coverage on different trypsin/particle ratios (measured mass ratio before the immobilization reaction) in the immobilization mixture (solid symbols). Control experiment was carried out without the use of covalent coupling agents, EDC and NHS (empty symbols). The amount of the immobilized trypsin was determined by Lowry's method after basic treatment of the particles (trypsin mobilization), the mass of the particles was measured by analytical balance. (b) The surface trypsin concentration increased linearly up to $10-15 \mu \mathrm{g} / \mathrm{mg}$, and stagnated if initial trypsin/particle was higher than $250 \mu \mathrm{g} / \mathrm{mg}$. 
packing (which does not include the fittings, only void space between the particles) is not higher than $50 \mathrm{~nL}$, which is probably overestimated. In this case, a $1 \mathrm{~cm}$ long packing contains $5 \mu \mathrm{g}$ immobilized trypsin and the dead volume contains $50 \mathrm{ng}$ protein (for $1 \mathrm{mg} / \mathrm{mL}$ sample concentration). Thus, the protein:enzyme ratio is 50:5000, while at in-solution digestion it is 50:1. As trypsin ratio is 5000-times higher, the reaction rate can be 5000 -times faster, as well. This is the reason why digestion with IMER can be performed under $10 \mathrm{~s}$, while a standard digestion takes $16 \mathrm{~h}$. If the dead volume was less than $50 \mathrm{~nL}$, the $5000 \times$ multiplier in reaction rate can be even higher.

\subsection{Reproducibility of the peptide maps}

To demonstrate the reproducibility of the analytical method, BSA samples were digested, desalted and analyzed via CZE. Reproducibility was examined from several aspects: reproducibility of CZE (the same digested BSA was analyzed four times - Fig. 3a); reproducibility of digestion (4 different BSA samples were digested with the same packing - Fig. 3b); reproducibility of the packing formation (BSA samples were digested on 4 different packings, the particles were prepared in the same immobilization reaction, Fig. 3c); and the reproducibility of immobilization (BSA samples were digested on 4 different packings, the particles were prepared in 4 different immobilization reactions, Fig. 3d). The electropherograms were matched by the correction of the migration times using two time references for two identical peaks
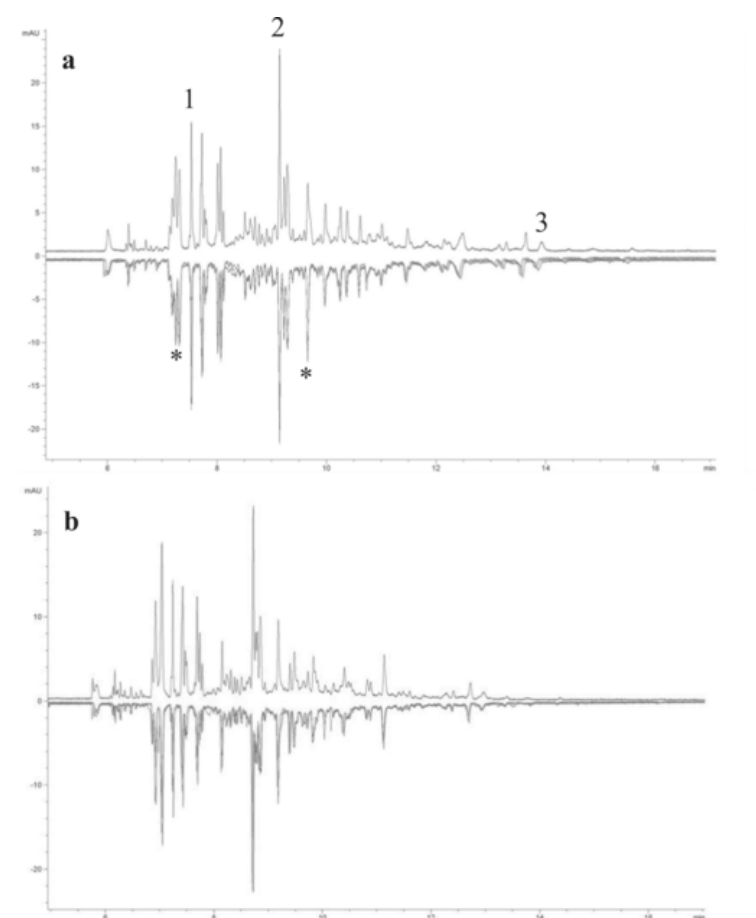

\begin{tabular}{c|c|c|c|c|c|c|}
\multirow{2}{*}{ e } & \multicolumn{9}{c|}{ RSD \% } \\
\cline { 2 - 7 } & \multicolumn{2}{|c|}{ Peak 1 } & \multicolumn{2}{c|}{ Peak 2 } & \multicolumn{2}{c|}{ Peak 3 } \\
\cline { 2 - 8 } & $\mathrm{t}$ & $\mathrm{A}$ & $\mathrm{t}$ & $\mathrm{A}$ & $\mathrm{t}$ & $\mathrm{A}$ \\
\hline & 0.03 & 2.51 & 0.02 & 2.18 & 0.31 & 9.13 \\
\hline (a) & 0.03 & 12.40 & 0.02 & 11.84 & 0.10 & 12.60 \\
\hline (b) & 0.05 & 30.55 & 0.04 & 23.36 & 0.14 & 53.57 \\
\hline (c) & 0.05 & 31.99 & 0.02 & 30.64 & 0.03 & 42.68 \\
\hline (d) & \multicolumn{7}{|c|}{} & & & & \\
\hline
\end{tabular}

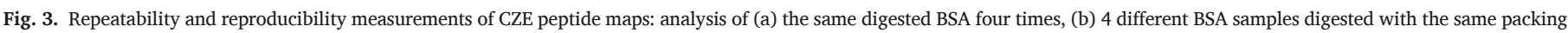

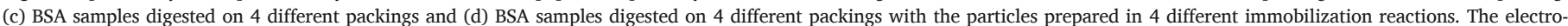

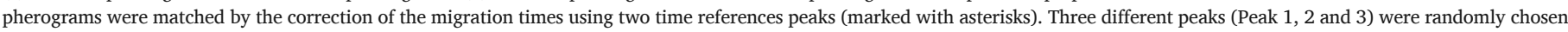

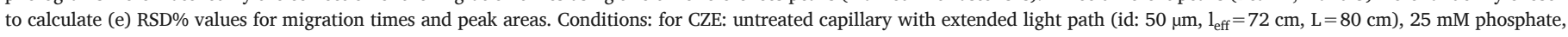
pH: $7,+30 \mathrm{kV}, 100$ mbar s, $\lambda=200 \mathrm{~nm}$. (marked with * in Fig. 3a) in order to compensate the shifts in the migration times of the peaks. Three different peaks (Peak 1 at $\sim 7.35 \mathrm{~min}$, Peak 2 at $\sim 8.8 \mathrm{~min}$ and Peak 3 at $\sim 13 \mathrm{~min}$ ) were randomly chosen to investigate the scattering of the migration times and peak areas, that are summarized in Fig. 3e. Integrated electropherograms are available in the Supplementary material (Fig. S.2 a-d).

Low $\mathrm{RSD} \%$ values $(<0.5 \%)$ were calculated for migration times, which can be a result of effective postconditioning and the application of matching with two time references. Also, since mostly identical peptides were formed in the microchip IMER during digestion, the peak patterns of the electropherograms are similar. The number of peaks ( $\sim 70-80)$ correlated well with the theoretically expected number [72] of peptides in the case of a complete digestion of albumin.

Higher RSD\% values were calculated for peak areas. For the reproducibility of CZE (a), RSD\% values were higher than usual (2-10\%) due to integration difficulties (the peaks were small (peak 3) or not baseline resolved (peak 1-2), Fig. S.3). There was higher RSD\% calculated for (b) and even higher for (c) and (d), but there is no significant difference between (c) and (d). It can be interpreted that different samples may uncontrollably contain the same peptides in different concentrations, because some hydrophilic peptides can be lost during desalination or because hydrophobic peptides can be adsorbed on the surface of the PDMS chip. The use of different packings for digestion further increased $\mathrm{RSD} \%$ values, as the different lab-made packings are not equally compressed, their formation is less reproducible. However, no
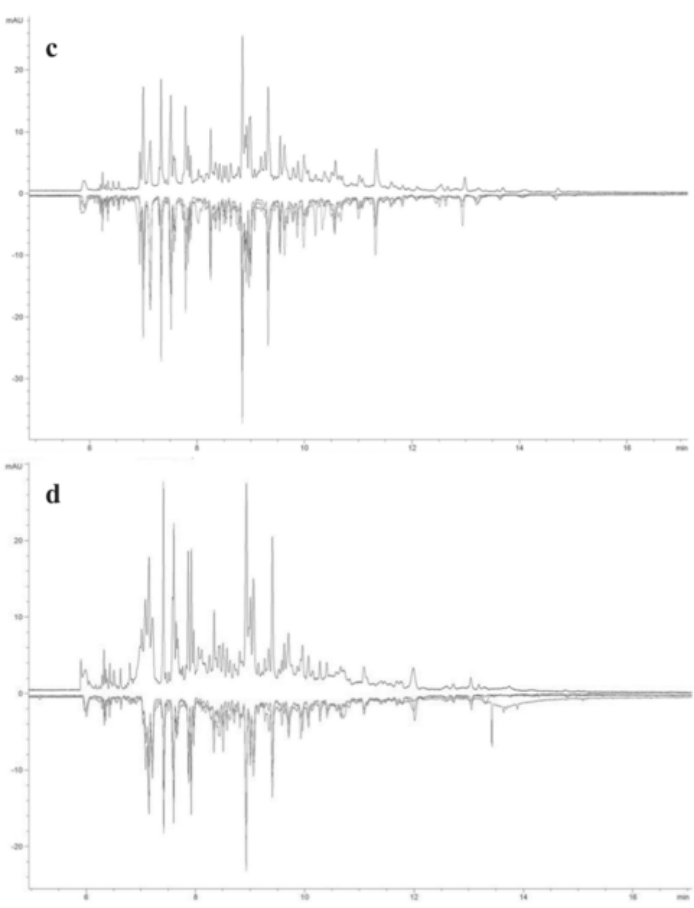
significant differences in RSD\% were experienced when digestion was executed in packings that were formed with particles from different immobilization mixtures. It may confirm the supposition that the surface of the particles was saturated with trypsin (in each case the ideal trypsin/ particle ratio was used).

\subsection{Stability and applicability of the microchip IMER for peptide mapping}

The stability of the reactor was tested with several experiments. After trypsin immobilization, BSA was digested with freshly prepared (immobilized and packed) microchip IMER and the digest was analyzed with CZE (Fig. 4a). The prepared particles were stored for 2 months at $-18{ }^{\circ} \mathrm{C}$ suspended in storage solution $\left(1 \mathrm{mM} \mathrm{HCl}, 20 \mathrm{mM} \mathrm{CaCl}{ }_{2}\right.$ and $0.4 \mathrm{mg} / \mathrm{mL}$ benzamidine). Also, the IMER was immersed into storage solution and was stored for 2 months at $4{ }^{\circ} \mathrm{C}$. After 2 months, BSA was digested on a microchip IMER freshly packed with the stored particles (Fig. 4b). Another BSA sample was digested with the microchip IMER stored for 2 months (Fig. 4c). The total amount of BSA was digested and the number of peptide peaks were equal in each sample. These experiments proved that immobilized trypsin retains its activity for at least 2 months and there is no difference if the particles were suspended in a solution or packed into a microchip IMER during storage.

Four proteins (myoglobin - $17 \mathrm{kDa}$, lysozyme - $16 \mathrm{kDa}$, hemoglobin - $62 \mathrm{kDa}$ and BSA - $69 \mathrm{kDa}$ ) were digested to evaluate the efficiency of the microchip IMER. In the case of a complete digestion with no missed cleavage, 19, 19, 31 and 78 peptides should be detected in the case of myoglobin, lysozyme, hemoglobin and BSA, respectively [72]. The CZE peptide maps of these proteins showed good correlation to the theo-
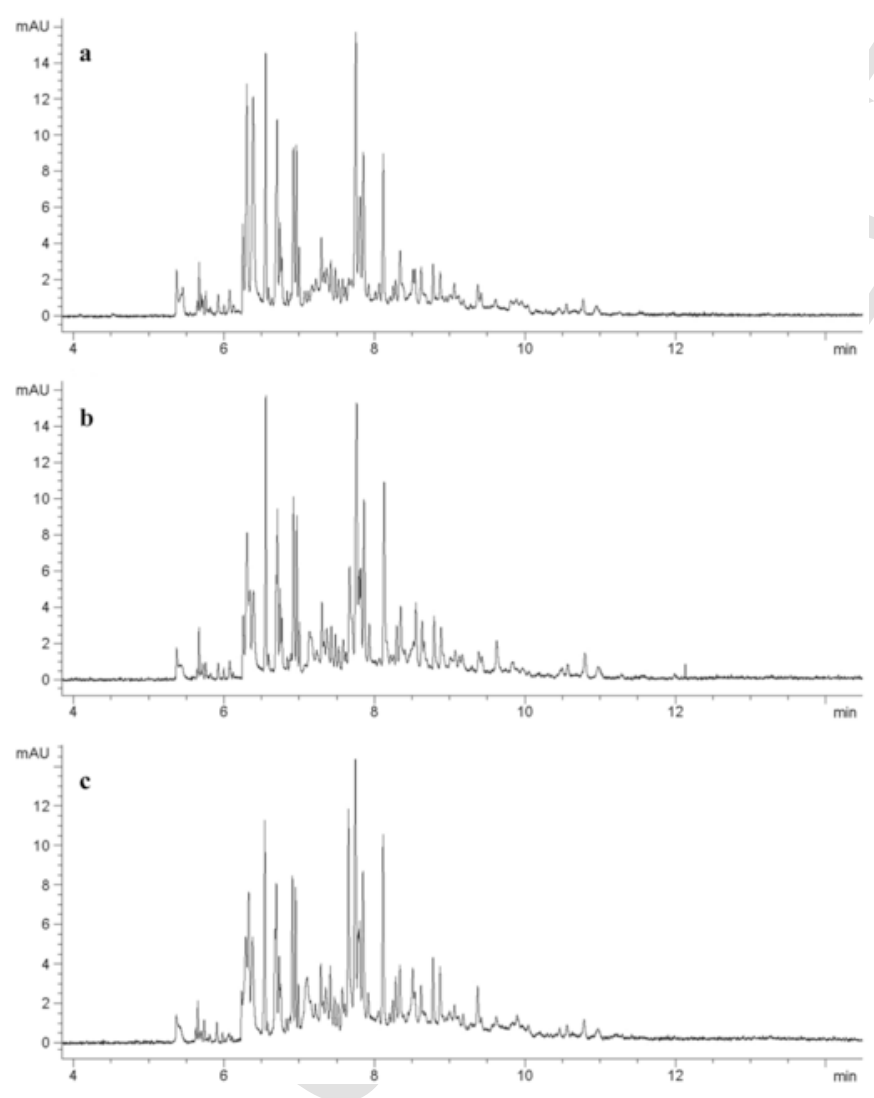

Fig. 4. Stability of the microchip IMER: digestion (a) with a freshly formed packing of freshly prepared immobilized trypsin particles, (b) with a freshly formed packing of immobilized trypsin particles prepared 2 months earlier and (c) with the packing formed 2 months earlier from immobilized trypsin particles. Conditions are the same as in Fig. 3. retically expected numbers after digestion with the microchip IMER (number of separated peaks were around 20, 20, 30 and 80 for the four protein, Fig. 5).

Each peptide map obtained from digestions with the microchip IMER was compared to the peptide maps obtained from standard in-solution digestions (Fig. 5). It can be concluded, that most of the separated and detected peptides were identical in both cases, based on the uniformity of the peak patterns, especially their migration times. The reaction time was typically $5-10 \mathrm{~s}$ when digestion was performed with the microchip IMER, while $16 \mathrm{~h}$ was needed for in-solution digestion, however, there was no significant difference between the efficiencies.

The digestion of the protein content of human serum was performed with the IMER. Fig. 6 shows that similar result was obtained with the standard in-solution digestion, as with the IMER digestion. The most abundant protein in the serum is albumin, 74 peptides can be derived from the perfect digestion of HSA. The number of peptide peaks correlates well with each other, and with the expected number, as well. This experiment proves that the IMER can be used for the digestion of realistic samples, too.

Protein identification was carried out via LC-MS/MS method. Four protein samples digested with the microchip IMER were identified (Table 1) with satisfying sequence coverage values (29-50\%), trypsin autolysis peptides were not detected in the samples. Sequence coverage and protein score values for each protein are listed in Table 1, identified peptides with the number of missed cleavages are listed individually in the Supplementary material (Table S.1).

BSA is often used to test the efficiency of trypsin containing IMERs. Sequence coverage value of digested BSA were $29 \%$ with our microchip IMER with $<10$ s reaction time. Several works reported comparable values: $22 \%$ and $30 \%$ (5 s reaction time) [22], $43 \%$ (5 min) [41], 46\% (5 min) [42], 23\% (12 min) [53], 35\% (24 s) [73], 45\% (10 s) [74] and $40 \%$ (5 s) [75] - with IMERs containing covalently linked trypsin on different solid supports. As a comparison with works published in this field, Table 2 contains the main parameters of covalently linked enzymatic microreactors, that use beads/particles as solid support for immobilization.

\section{Conclusions}

In this paper we reported the preparation of a simple, inexpensive microchip IMER, capable of rapid proteolysis. Protein digestion is a crucial analysis step in peptide mapping, however, standard in-solution digestion is time-consuming $(16 \mathrm{~h})$. The proposed microchip IMER contains trypsin immobilized on conventional silica particles. The micropackings can be prepared easily with the use of bottlenecks that retain the particles. The properly compressed packings offer high S/V ratio which is essential for high reaction rate in a heterogenic reaction. On the basis of the determined immobilized trypsin per particle, reaction rates can be higher by at least 3 orders of magnitude.

Reproducibility of CZE measurements, digestion, packing preparation and immobilization was investigated, in each case good RSD\% values were calculated for migration times. The CZE peptide maps (peak pattern) obtained by microchip IMER digestion and in-solution digestion did not differ significantly, however, microchip IMER digestion takes $<10 \mathrm{~s}$. Human serum was also digested efficiently with the IMER. The 4 microchip IMER digested proteins were identified with LC-MS/ MS, sequence coverage values were sufficient (29-50\%). Trypsin autolysis peptides were not identified.

The microchip IMER is a high throughput device enabling the simultaneous digestion of 9 samples. Since, only $1 \mu \mathrm{L}$ sample is needed for LC-MS/MS analysis (which is diluted to the final $10 \mu \mathrm{L}$ ), using this technique $1 \mathrm{~min}$ can be enough for the digestion of 9 samples (flow rate: $1 \mu \mathrm{L} / \mathrm{min}$ ). The microchip IMER is made of PDMS, a low-cost 

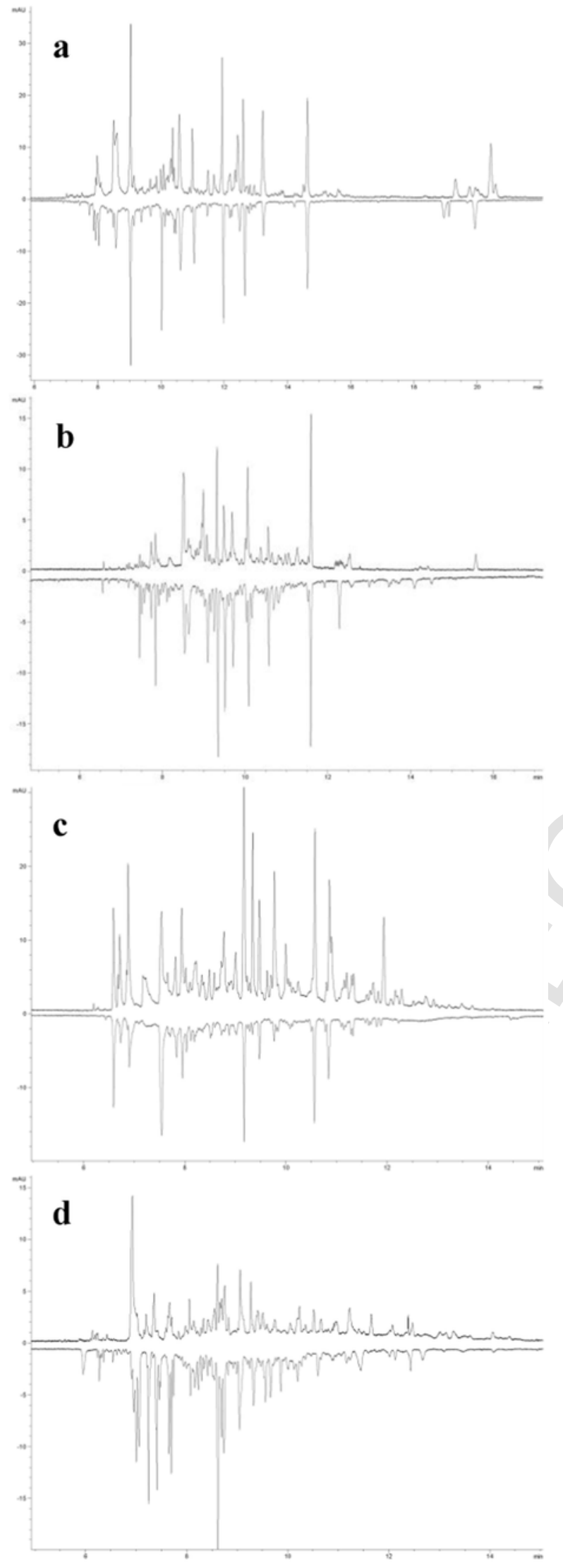

Fig. 5. Digestion of four proteins: (a) myoglobin, (b) lysozyme, (c) hemoglobin and (d) BSA. Upper electropherograms are peptide maps obtained from standard in-solution di- gestions of these proteins (reaction time: $16 \mathrm{~h}$ ), while mirrored electropherograms are from microchip IMER digestions (reaction time $<10 \mathrm{~s}$ ). Conditions are the same as in Fig. 3 .

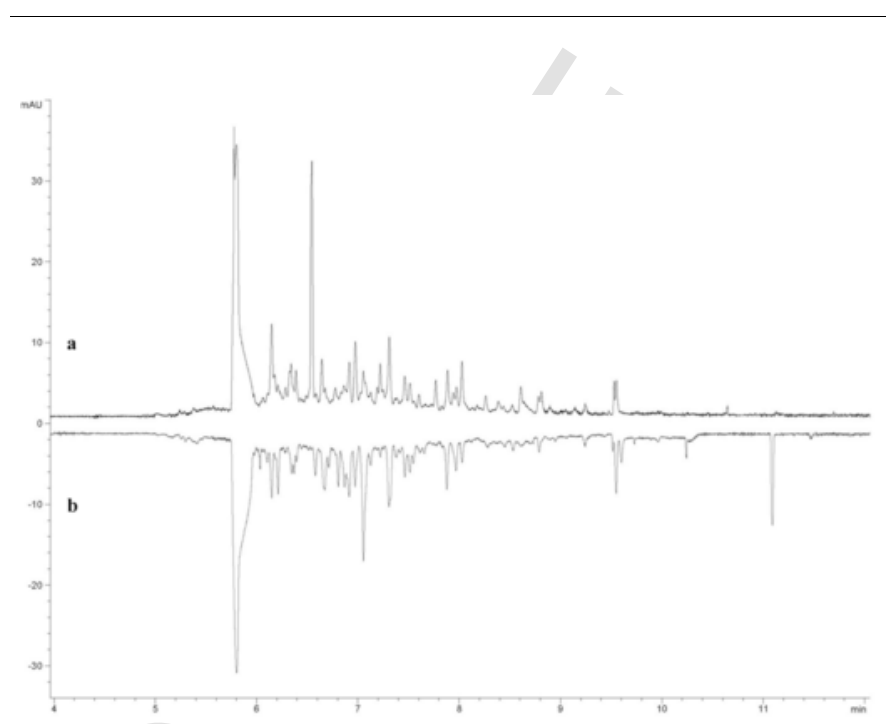

Fig. 6. Electropherograms of digested human serum using (a) standard in-solution digestion and (b) microchip IMER digestion. Injected sample: $200 \mathrm{mbar} s$, further conditions are the same as in Fig. 3.

Table 1

LC-MS/MS peptide mapping analysis of four proteins from microchip IMER digestion. In dividual peptide sequences are available in Supplementary material.

\begin{tabular}{|c|c|c|c|}
\hline Protein name & $\begin{array}{l}\text { Nominal mass } \\
\text { (Da) }\end{array}$ & $\begin{array}{l}\text { Sequence } \\
\text { coverage (\%) }\end{array}$ & $\begin{array}{l}\text { Protein } \\
\text { score }\end{array}$ \\
\hline Lysozyme & 16,228 & 50 & 370 \\
\hline Myoglobin & 17,072 & 50 & 372 \\
\hline $\begin{array}{l}\text { Hemoglobin } \\
\text { subunit } \alpha\end{array}$ & 15,130 & 31 & 197 \\
\hline $\begin{array}{l}\text { Hemoglobin } \\
\text { subunit } \beta\end{array}$ & 15,944 & 40 & 379 \\
\hline $\begin{array}{l}\text { Bovine serum } \\
\text { albumin }\end{array}$ & 69,248 & 29 & 853 \\
\hline
\end{tabular}

polymer, and it can be used for at least 2 months for multiple protein digestion. Although many immobilized trypsin reactors have been described earlier, the proposed microchip IMER can be an attractive alternative to those and the commercially available trypsin beads due to its high activity, high-throughput property, reusability, cost-efficiency and to its simple preparation.

\section{Acknowledgments}

The research was supported by the EU and co-financed by the European Regional Development Fund under the project GINOP-2.3.2-15-2016-00008, GINOP-2.3.3-15-2016-00004 and NTP-EFÖ-P-15-0003 project. The authors also acknowledge the financial support provided to this project by the National Research, Development and Innovation Office, Hungary (K111932). We thank Dr. Éva Csősz at Department of Biochemistry and Molecular Biology, University of Debrecen for help with mass spectrometric determinations.

\section{Appendix A. Supplementary material}

Supplementary data associated with this article can be found in the online version at doi:10.1016/j.talanta.2017.01.060. 
Table 2

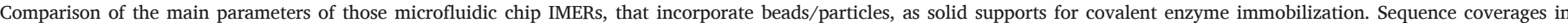

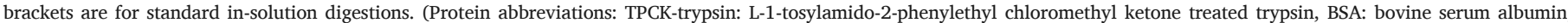

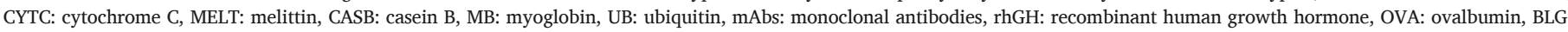
$\beta$-lactoglobulin, HIgG: human immunoglobulin, LYZ: lysozyme, HB: hemoglobin).

\begin{tabular}{|c|c|c|c|c|c|c|c|}
\hline $\begin{array}{l}\text { Immobilized } \\
\text { enzyme }\end{array}$ & Reactor type & $\begin{array}{l}\text { Type of } \\
\text { solid } \\
\text { support }\end{array}$ & $\begin{array}{l}\text { Digestion } \\
\text { time }\end{array}$ & $\begin{array}{l}\text { Digested } \\
\text { proteins }\end{array}$ & $\begin{array}{l}\text { Sequence } \\
\text { coverage } \\
(\%)\end{array}$ & Additional information & Ref. \\
\hline \multirow[t]{3}{*}{ TPCK-trypsin } & Glass microchip & $\begin{array}{l}\text { Agarose } \\
\text { bead }\end{array}$ & $\begin{array}{l}3-6 \mathrm{~min} \\
5 \mathrm{~s}\end{array}$ & BSA & & $40-60 \mu \mathrm{m}$ particle & {$[52]$} \\
\hline & & & & CYT C & 71 & & \\
\hline & & & & MELT & 92 & & \\
\hline \multirow[t]{3}{*}{ TPCK-trypsin } & Glass microchip & $\begin{array}{l}\text { Agarose } \\
\text { bead }\end{array}$ & $12 \mathrm{~min}$ & BSA & & & [53] \\
\hline & & & & CYT C & & & \\
\hline & & & & CASB & & & \\
\hline \multirow[t]{3}{*}{ Pepsin } & PMMA microchip & $\begin{array}{l}\text { Agarose } \\
\text { bead }\end{array}$ & $4-15 s$ & BSA & $34-88$ & & {$[54]$} \\
\hline & & & & MB & 99 & - & \\
\hline & & & & UB & 64 & & \\
\hline PNGase F & $\begin{array}{l}\text { Polyimide } \\
\text { microchip } \\
\text { (commercial) }\end{array}$ & $\begin{array}{l}\text { Silica } \\
\text { particles }\end{array}$ & - & mAbs & - & $\begin{array}{l}5 \mu \mathrm{m} \text { silica particles } \\
\text { glycoprotein analysis }\end{array}$ & {$[28]$} \\
\hline TPCK-trypsin & Glass microchip & $\begin{array}{l}\text { Magnetic } \\
\text { bead }\end{array}$ & $5 \mathrm{~min}$ & CYT C & $77(76)$ & $\begin{array}{l}300 \mathrm{~nm} \text { particle, realistic } \\
\text { sample: rat liver extract }\end{array}$ & {$[38]$} \\
\hline Proteinase K & PDMS microchip & $\begin{array}{l}\text { magnetic } \\
\text { bead }\end{array}$ & $3 \mathrm{~min}$ & $\begin{array}{l}\text { prion } \\
\text { proteins }\end{array}$ & 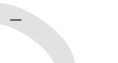 & $500 \mathrm{~nm}$ particle & [39] \\
\hline $\begin{array}{l}\text { Trypsin TPCK- } \\
\text { trypsin }\end{array}$ & PDMS microchip & $\begin{array}{l}\text { Magnetic } \\
\text { bead }\end{array}$ & $10 \mathrm{~min}$ & rhGH & $44(44)$ & $\begin{array}{l}626 \mathrm{~nm} \text { particle, native trypsin } \\
\text { - higher activity }\end{array}$ & [40] \\
\hline \multirow[t]{2}{*}{ TPCK-trypsin } & Glass microchip & $\begin{array}{l}\text { Magnetic } \\
\text { bead }\end{array}$ & $10 \mathrm{~s}$ & BSA & 43 & $\begin{array}{l}50 \mathrm{~nm} \text { particle, } 86 \mu \mathrm{g} \text { trypsin/ } \\
\text { mg particle, realistic sample: } \\
\text { rat liver extract }\end{array}$ & [41] \\
\hline & & & & $\begin{array}{l}\text { CYT C } \\
\text { MB }\end{array}$ & $\begin{array}{l}83 \\
79\end{array}$ & & \\
\hline \multirow[t]{2}{*}{$\begin{array}{l}\text { Trypsin TPCK- } \\
\text { trypsin }\end{array}$} & PDMS microchip & $\begin{array}{l}\text { Magnetic } \\
\text { bead }\end{array}$ & $22.5 \mathrm{~min}$ & BSA & & $0.29-10 \mu \mathrm{m}$ particle & [43] \\
\hline & & & & $\begin{array}{l}\text { BLG } \\
\text { HIgG }\end{array}$ & 37 & & \\
\hline \multirow[t]{4}{*}{ Trypsin } & PDMS microchip & $\begin{array}{l}\text { Silica } \\
\text { particles }\end{array}$ & $10 \mathrm{~s}$ & BSA & 29 & $5 \mu \mathrm{m}$ silica particles & $\begin{array}{l}\text { Present } \\
\text { work }\end{array}$ \\
\hline & & & & MB & 50 & & \\
\hline & & & & LYZ & 50 & & \\
\hline & & & & HB & $31-40$ & & \\
\hline
\end{tabular}

\section{References}

[1] M.R. Wilkins, J.-C. Sanchez, A.A. Gooley, R.D. Appel, I. Humphery-Smith, D.F Hochstrasser, et al., Progress with proteome projects: why all proteins expressed by a genome should be identified and how to do it, Biotechnol. Genet. Eng. Rev. 13 (1996) 19-50.

[2] M.P. Washburn, D. Wolters, J.R. Yates, Large-scale analysis of the yeast proteome by multidimensional protein identification technology, Nat. Biotechnol. 19 (2001) 242-247.

[3] H.K. Hustoft, H. Malerod, S.R. Wilson, L. Reubsaet, E. Lundanes, T. Greibrokk, A critical review of trypsin digestion for LC-MS based proteomics, in: Integrated Proteomics, InTech, Rijeka, 2012

[4] D.R. Stoll, P.W. Carr, Fast, comprehensive two-dimensional HPLC separation of tryptic peptides based on high-temperature HPLC, J. Am. Chem. Soc. 127 (2005) 5034-5035.

[5] K.A. Cobb, M. Novotny, High-sensitivity peptide mapping by capillary zone elec trophoresis and microcolumn liquid chromatography, using immobilized trypsin for protein digestion, Anal. Chem. 61 (1989) 2226-2231.

[6] M. Ye, S. Hu, R.M. Schoenherr, N.J. Dovichi, On-line protein digestion and peptide mapping by capillary electrophoresis with post-column labeling for laser-induced fluorescence detection, Electrophoresis 25 (2004) 1319-1326.

[7] M. Zeisbergerova, A. Adamkova, Z. Glatz, Integration of on-line protein digestion by trypsin in CZE by means of electrophoretically mediated microanalysis, Electrophoresis 30 (2009) 2378-2384.

[8] E. Bonneil, M. Mercier, K.C. Waldron, Reproducibility of a solid-phase trypsin microreactor for peptide mapping by capillary electrophoresis, Anal. Chim. Acta 404 (2000) 29-45.

[9] S. Ekström, P. Önnerfjord, J. Nilsson, M. Bengtsson, T. Laurell, G. Marko-Varga, Integrated microanalytical technology enabling rapid and automated protein identification, Anal. Chem. 72 (2000) 286-293.
[10] P. Huang, Jing-TaoWu, D.M. Lubman, Separation of tryptic digests using a modified buffer in pressurized capillary electrochromatography with an ion trap storage/reflectron time-of-flight mass spectrometer, Anal. Chem. 70 (1998) 3003-3008.

[11] S. Feng, M. Ye, X. Jiang, W. Jin, H. Zou, Coupling the immobilized trypsin microreactor of monolithic capillary with $\mu$ RPLC - MS/MS for shotgun proteome analysis, J. Proteome Res. 5 (2006) 422-428.

[12] N.I. Govorukhina, T.H. Reijmers, S.O. Nyangoma, A.G.J. van der Zee, R.C. Jansen, R. Bischoff, Analysis of human serum by liquid chromatography-mass spectrometry: improved sample preparation and data analysis, J. Chromatogr. A. 1120 (2006) 142-150.

[13] M. Mann, O.N. Jensen, Proteomic analysis of post-translational modifications, Nat. Biotechnol. 21 (2003) 255-261.

[14] A. Sassolas, L.J. Blum, B.D. Leca-Bouvier, Immobilization strategies to develop enzymatic biosensors, Biotechnol. Adv. 30 (2012) 489-511.

[15] R. Messing, Immobilized enzymes for industrial reactors, in: Immobil. Enzym. Ind React., Academic Press, New York, 1975

[16] R.C. Rodrigues, C. Ortiz, A. Berenguer-Murcia, R. Torres, R. Fernandez-Lafuente, Modifying enzyme activity and selectivity by immobilization, Chem. Soc. Rev. 42 (2013) 6290-6307.

[17] J.W. Cooper, J. Chen, Y. Li, C.S. Lee, Membrane-based nanoscale proteolytic reactor enabling protein digestion, peptide separation, and protein identification using mass spectrometry, Anal. Chem. 75 (2003) 1067-1074.

[18] J. Gao, J. Xu, L.E. Locascio, C.S. Lee, Integrated microfluidic system enabling protein digestion, peptide separation, and protein identification, Anal. Chem. 73 (2001) 2648-2655.

[19] F. Xu, W.-H. Wang, Y.-J. Tan, M.L. Bruening, Facile trypsin immobilization in polymeric membranes for rapid, efficient protein digestion, Anal. Chem. 82 (2010) 10045-10051.

[20] D. Goradia, J. Cooney, B.K. Hodnett, E. Magner, The adsorption characteristics, activity and stability of trypsin onto mesoporous silicates, J. Mol. Catal. B Enzym. 32 (2005) 231-239. 
[21] Y. Jiang, C.S. Lee, On-line coupling of micro-enzyme reactor with micro-membrane chromatography for protein digestion, peptide separation, and protein identification using electrospray ionization mass spectrometry, J. Chromatogr. A 924 (2001) 315-322.

[22] H. Wu, J. Zhai, Y. Tian, H. Lu, X. Wang, W. Jia, et al., Microfluidic enzymatic-reactors for peptide mapping: strategy, characterization, and performance, Lab Chip 4 (2004) 588-597.

[23] Q. Min, R. Wu, L. Zhao, H. Qin, M. Ye, J.-J. Zhu, et al., Size-selective proteolysis on mesoporous silica-based trypsin nanoreactor for low-MW proteome analysis, Chem. Commun. 46 (2010) 6144-6146.

[24] J. Ma, Z. Liang, X. Qiao, Q. Deng, D. Tao, L. Zhang, et al., Organic-inorganic hybrid silica monolith based immobilized trypsin reactor with high enzymatic activity, Anal. Chem. 80 (2008) 2949-2956.

[25] E. Calleri, C. Temporini, E. Perani, C. Stella, S. Rudaz, D. Lubda, et al., Development of a bioreactor based on trypsin immobilized on monolithic support for the on-line digestion and identification of proteins, J. Chromatogr. A 1045 (2004) 99-109.

[26] J. Krenkova, K. Kleparnik, F. Foret, Capillary electrophoresis mass spectrometry coupling with immobilized enzyme electrospray capillaries, J. Chromatogr. A 1159 (2007) 110-118.

[27] L. Sun, Y. Li, P. Yang, G. Zhu, N.J. Dovichi, High efficiency and quantitatively reproducible protein digestion by trypsin-immobilized magnetic microspheres, $\mathrm{J}$ Chromatogr. A 1220 (2012) 68-74.

[28] M.A. Bynum, H. Yin, K. Felts, Y.M. Lee, C.R. Monell, K. Killeen, Characterization of IgG N-glycans employing a microfluidic chip that integrates glycan cleavage, sample purification, LC separation, and MS detection, Anal. Chem. 81 (2009) 8818-8825.

[29] M.T. Davis, T.D. Lee, M. Ronk, S.A. Hefta, Microscale immobilized protease reacto columns for peptide mapping by liquid chromatography/mass spectral analyses, Anal. Biochem. 224 (1995) 235-244.

[30] D. Dogruel, P. Williams, R.W. Nelson, Rapid tryptic mapping using enzymatically active mass spectrometer probe tips, Anal. Chem. 67 (1995) 4343-4348.

[31] J.R. Freije, P.P.M.F.A. Mulder, W. Werkman, L. Rieux, H.A.G. Niederlander, E. Ver poorte, et al., Chemically modified, immobilized trypsin reactor with improved digestion efficiency, J. Proteome Res. 4 (2005) 1805-1813.

[32] Y. Li, R. Wojcik, N.J. Dovichi, A replaceable microreactor for on-line protein digestion in a two-dimensional capillary electrophoresis system with tandem mass spectrometry detection, J. Chromatogr. A 1218 (2011) 2007-2011.

[33] M.T. Dulay, Q.J. Baca, R.N. Zare, Enhanced proteolytic activity of covalently bound enzymes in photopolymerized sol gel, Anal. Chem. 77 (2005) 4604-4610.

[34] R. Nicoli, S. Rudaz, C. Stella, J.-L. Veuthey, Trypsin immobilization on an ethylenediamine-based monolithic minidisk for rapid on-line peptide mass fingerprinting studies, J. Chromatogr. A 1216 (2009) 2695-2699.

[35] S. Ota, S. Miyazaki, H. Matsuoka, K. Morisato, Y. Shintani, K. Nakanishi, High-throughput protein digestion by trypsin-immobilized monolithic silica with pipette-tip formula, J. Biochem. Biophys. Methods 70 (2007) 57-62.

[36] C. Temporini, E. Perani, E. Calleri, L. Dolcini, D. Lubda, G. Caccialanza, et al., Pronase-immobilized enzyme reactor: an approach for automation in glycoprotein analysis by LC/LC-ESI/MS , Anal. Chem. 79 (2007) 355-363.

[37] R. Nicoli, N. Gaud, C. Stella, S. Rudaz, J.-L. Veuthey, Trypsin immobilization on three monolithic disks for on-line protein digestion, J. Pharm. Biomed. Anal. 48 (2008) 398-407.

[38] Y. Li, B. Yan, C. Deng, W. Yu, X. Xu, P. Yang, et al., Efficient on-chip proteolysis system based on functionalized magnetic silica microspheres, Proteomics 7 (2007) 2330-2339.

[39] A. Le Nel, N. Minc, C. Smadja, M. Slovakova, Z. Bilkova, J.-M. Peyrin, et al., Controlled proteolysis of normal and pathological prion protein in a microfluidic chip Lab Chip 8 (2008) 294-301.

[40] M. Slovakova, N. Minc, Z. Bilkova, C. Smadja, W. Faigle, C. Futterer, et al., Use of self assembled magnetic beads for on-chip protein digestion, Lab Chip 5 (2005) 935-942.

[41] J. Liu, S. Lin, D. Qi, C. Deng, P. Yang, X. Zhang, On-chip enzymatic microreacto using trypsin-immobilized superparamagnetic nanoparticles for highly efficient proteolysis, J. Chromatogr. A 1176 (2007) 169-177.

[42] Y. Li, X. Xu, C. Deng, P. Yang, X. Zhang, Immobilization of trypsin on superparamagnetic nanoparticles for rapid and effective proteolysis, J. Proteome Res. 6 (2007) 3849-3855.

[43] Z. Bilkova, M. Slovakova, N. Minc, C. Futterer, R. Cecal, D. Horak, et al., Functionalized magnetic micro- and nanoparticles: optimization and application to $\mu$-chip tryptic digestion, Electrophoresis 27 (2006) 1811-1824.

[44] J. Duan, Z. Liang, C. Yang, J. Zhang, L. Zhang, W. Zhang, et al., Rapid protein identification using monolithic enzymatic microreactor and LC-ESI-MS/MS, Proteomics 6 (2006) 412-419.

[45] L.N. Amankwa, W.G. Kuhr, Trypsin-modified fused-silica capillary microreactor for peptide mapping by capillary zone electrophoresis, Anal. Chem. 64 (1992) $1610-1613$.

[46] H. Mao, T. Yang, P.S. Cremer, Design and characterization of immobilized enzyme in microfluidic systems, Anal. Chem. 74 (2002) 379-385.

[47] L. Licklider, W.G. Kuhr, M.P. Lacey, T. Keough, M.P. Purdon, R. Takigiku, Online microreactors/capillary electrophoresis/mass spectrometry for the analysis of proteins and peptides, Anal. Chem. 67 (1995) 4170-4177.
[48] S. Liu, H. Bao, L. Zhang, G. Chen, Efficient proteolysis strategies based on microchip bioreactors, J. Proteom. 82 (2013) 1-13.

[49] Y. Liu, H. Lu, W. Zhong, P. Song, J. Kong, P. Yang, et al., Multilayer-assembled microchip for enzyme immobilization as reactor toward low-level protein identification, Anal. Chem. 78 (2006) 801-808.

[50] R.M. Schoenherr, M. Ye, M. Vannatta, N.J. Dovichi, CE-microreactor-CE-MS/MS for protein analysis, Anal. Chem. 79 (2007) 2230-2238.

[51] Y. Li, X. Xu, B. Yan, C. Deng, W. Yu, P. Yang, et al., Microchip reactor packed with metal-ion chelated magnetic silica microspheres for highly efficient proteolysis, J. Proteome Res. 6 (2007) 2367-2375.

[52] C. Wang, R. Oleschuk, F. Ouchen, J. Li, P. Thibault, D.J. Harrison, Integration of immobilized trypsin bead beds for protein digestion within a microfluidic chip incorporating capillary electrophoresis separations and an electrospray mass spectrometry interface, Rapid Commun, Mass Spectrom. 14 (2000) 1377-1383.

[53] L.J. Jin, J. Ferrance, J.C. Sanders, J.P. Landers, A microchip-based proteolytic digestion system driven by electroosmotic pumping, Lab Chip 3 (2003) 11-18.

[54] P. Liuni, T. Rob, D.J. Wilson, A microfluidic reactor for rapid, low-pressure proteolysis with on-chip electrospray ionization, Rapid Commun. Mass Spectrom. 24 (2010) 315-320.

[55] M. Brivio, R.H. Fokkens, W. Verboom, D.N. Reinhoudt, N.R. Tas, M. Goedbloed, et al., Integrated microfluidic system enabling (bio)chemical reactions with on-line MALDI-TOF mass spectrometry, Anal. Chem. 74 (2002) 3972-3976.

[56] D. Figeys, Y. Ning, R. Aebersold, A microfabricated device for rapid protein identification by microelectrospray ion trap mass spectrometry, Anal. Chem. 69 (1997) 3153-3160.

[57] B. Zhang, H. Liu, B.L. Karger, F. Foret, Microfabricated devices for capillary electrophoresis - electrospray mass spectrometry, Anal. Chem. 71 (1999) 3258-3264.

[58] J. Lee, S.A. Soper, K.K. Murray, Microfluidic chips for mass spectrometry-based proteomics, J. Mass Spectrom. 44 (2009) 579-593.

[59] G. Massolini, E. Calleri, Immobilized trypsin systems coupled on-line to separation methods: recent developments and analytical applications, J. Sep. Sci. 28 (2005) $7-21$.

[60] G.M. Whitesides, E. Ostuni, S. Takayama, X. Jiang, D.E. Ingber, Soft lithography in biology and biochemistry, Annu. Rev. Biomed. Eng. 3 (2001) 335-373.

[61] A. Nagy, A. Gaspar, Packed multi-channels for parallel chromatographic separations in microchips, J. Chromatogr. A. 1304 (2013) 251-256.

[62] A. Nagy, E. Baranyai, A. Gaspar, Interfacing microfluidic chip-based chromatography with flame atomic absorption spectrometry for the determination of chromium(VI), Microchem. J. 114 (2014) 216-222.

[63] A. Nagy, E.L. Toth, K. Ivan, A. Gaspar, Design and modeling of microfluidic systems for multiple chromatographic separations, Microchem. J. 123 (2015) $125-130$.

[64] O.H. Lowry, N.J. Rosebrough, A.L. Farr, R.J. Randall, Protein measurement with the Folin phenol reagent, J. Biol. Chem. 193 (1951) 265-275.

[65] D.S. Peterson, T. Rohr, F. Svec, J.M.J. Frechet, High-throughput peptide mass mapping using a microdevice containing trypsin immobilized on a porous polymer monolith coupled to MALDI-TOF and ESI-TOF mass spectrometers, J. Proteome Res. 1 (2002) 563-568.

[66] J. Krenkova, Z. Bilkova, F. Foret, Characterization of a monolithic immobilized trypsin microreactor with on-line coupling to ESI-MS, J. Sep. Sci. 28 (2005) $1675-1684$.

[67] J. Duan, L. Sun, Z. Liang, J. Zhang, H. Wang, L. Zhang, et al., Rapid protein digestion and identification using monolithic enzymatic microreactor coupled with nano-liquid chromatography-electrospray ionization mass spectrometry, J. Chromatogr. A. 1106 (2006) 165-174.

[68] L. Sun, G. Zhu, X. Yan, S. Mou, N.J. Dovichi, Uncovering immobilized trypsin digestion features from large-scale proteome data generated by high-resolution mass spectrometry, J. Chromatogr. A. 1337 (2014) 40-47.

[69] A.K. Palm, M.V. Novotny, Analytical characterization of a facile porous polymer monolithic trypsin microreactor enabling peptide mass mapping using mass spectrometry, Rapid Commun. Mass Spectrom. 18 (2004) 1374-1382.

[70] L. Sun, G. Zhu, N.J. Dovichi, Integrated capillary zone electrophoresis-electrospray ionization tandem mass spectrometry system with an immobilized trypsin microreactor for online digestion and analysis of picogram amounts of RAW 264.7 cell lysate, Anal. Chem. 85 (2013) 4187-4194.

[71] K. Sakai-Kato, M. Kato, T. Toyo'oka, On-line trypsin-encapsulated enzyme reactor by the sol - gel method integrated into capillary electrophoresis, Anal. Chem. 74 (2002) 2943-2949.

[72] E. Gasteiger, C. Hoogland, A. Gattiker, S. Duvaud, M.R. Wilkins, R.D. Appel, et al., Protein identification and analysis tools on the ExPASy server, The Proteomics Protocols Handbook, Humana Press Totowa, NJ, 2005, pp. 571-607

[73] J. Lee, H.K. Musyimi, S.A. Soper, K.K. Murray, Development of an automated digestion and droplet deposition microfluidic chip for MALDI-TOF MS, J. Am. Soc. Mass Spectrom. 19 (2008) 964-972.

[74] T. Liu, S. Wang, G. Chen, Immobilization of trypsin on silica-coated fiberglass core in microchip for highly efficient proteolysis, Talanta 77 (2009) 1767-1773.

[75] H. Fan, G. Chen, Fiber-packed channel bioreactor for microfluidic protein digestion, Proteomics 7 (2007) 3445-3449. 